\title{
BOARD OF PUBLIC INSTRUCTION ข. FINCH: UNWARRANTED COMPROMISE OF TITLE VI'S TERMINATION SANCTION
}

Title VI of the Civil Rights Act of $1964^{1}$ was enacted with the hope that administrative efforts might counter the failure of court enforcement and assure Negro children their constitutional right to a desegregated education. Title VI provides in part that

no person in the United States shall, on the ground of race, color, or national origin, be excluded from participation in, be denied the benefits of, or be subjected to discrimination under any program or activity receiving federal financial assistance. $^{2}$

Title VI was more than a reaffirmation of national policy; it was the basis for an alternative approach to school desegregation. Every federal agency administering financial assistance is thereby entrusted with the additional duty of putting an end to discrimination in federally assisted programs. If discrimination continues, section 602 of title VI authorizes "the termination of or refusal to grant or to continue assistance under such program or activity . . . ." 3 In short, title VI imposed on the Department of Health, Education, and Welfare's Office of Education the responsibility for desegregating all school districts receiving federal assistance. To enforce its orders, $\mathrm{HEW}$ was given the right to terminate federal aid to any school district refusing to comply.

Although section 602 explicitly confines the termination of assistance to the political entity and particular program for which a finding of noncompliance has been made, ${ }^{4} \mathrm{HEW}$ 's termination procedures, until recently, considered a school district's basic elementary and secondary education system to be a single "program." No attempt was made to separate funds into areas (such as remedial reading or adult education) delimited by the specific authorizing legislation. Termination procedures did not require a finding of discriminatory use of funds under each grant statute because departmental resources were thought inadequate to make such a finding and, more importantly, because $\mathrm{HEW}$ believed that the individual parts of an educational system should not be examined separately to determine if discrimination infects particular parts. Thus, discrimination in any federally assisted school activity

\footnotetext{
142 U.S.C. $\$ 2000$ d to -4 (1964).

2 Id. $\$ 2000 \mathrm{~d}$.

${ }^{3}$ Id. $\$ 2000 \mathrm{~d}-1$.

4 Id.
} 
tainted the entire system. Similarly, a general condition of segregation in elementary and secondary classrooms was thought to reach all parts of the system. In Board of Public Instruction v. Finch (Taylor County), ${ }^{5}$ the Fifth Circuit ruled that HEW could no longer consider a district's basic elementary and secondary educational system to be a single federally supported "program" but "must make findings of fact indicating either that a particular program is itself administered in a discriminatory manner, or is so affected by discriminatory practices elsewhere in the school system that it thereby becomes discriminatory." 6 Within the meaning of section 602, "program" was held to refer to individual grant statutes. This Comment contends that the Fifth Circuit's construction of section 602 seriously compromises title VI as an effective complement to federal court enforcement for desegregating public education.

\section{Board of Public Instruction v. Finch}

Following the passage of the Civil Rights Act of 1964, the Board of Public Instruction of Taylor County, Florida, adopted a freedom of choice plan complying with the Office of Education's established desegregation guidelines. ${ }^{7}$ Subsequently, in March 1966, the Board submitted an assurance of compliance with the requirements of the revised guidelines issued by the Office of Education. Despite this assurance, the Board failed to implement desegregation at the pace required by the guidelines. For example, during the 1965-66 school year, only 10 of 975 Negro students attended formerly all-white schools. For the school year 1967-68, Taylor County officials agreed to transfer 74 Negro students to white schools and to begin assignment of teachers across racial lines. Again, these commitments fell far below the guideline requirements.

In an effort to secure voluntary compliance with the guidelines, HEW representatives met with Taylor County school officials several times during the spring of 1967 . When these meetings failed to bring about increased compliance, the matter was referred to an HEW hearing examiner who ruled on April 4, 1968, that the Taylor County school system's inadequate progress toward student and faculty desegregation constituted a violation of title VI of the 1964 Civil Rights Act. The examiner entered an order terminating all federal aid to education allocated to Taylor County. The order, subsequently approved by the reviewing authority, cut off $\$ 204,197.55$ in aid administered under three grant statutes. ${ }^{8}$

5414 F.2d 1068 (5th Cir. 1969).

6 Id. at 1079.

7 The factual background of the case is discussed at $i d$. at 1070-71.

8 The grant statutes involved were: Elementary and Secondary Education Act of 1965 tit. II, 20 U.S.C. $\$ \$ 241 \mathrm{a}-241 \mathrm{~m}$ (Supp. IV, 1969); Elementary and Secondary Education Act of 1965 tit. III, 20 U.S.C. $\$ 841-48$ (Supp. IV, 1969); and Adult Education Act of $1966 \S \S 302-14,20$ U.S.C. \$\$1201-13 (Supp. IV, 1969). 
On appeal, the Board argued that HEW's order terminating Taylor County's aid to education violated section 602 of the Civil Rights Act. That section provides, in relevant part:

Compliance with any requirement adopted pursuant to this section may be effected (1) by the termination of or refusal to grant or to continue assistance under such program or activity to any recipient as to whom there has been an express finding on the record, after opportunity for hearing, of a failure to comply with such requirement, but such termination or refusal shall be limited to the particular political entity, or part thereof, or other recipient as to whom such a finding has been made and, shall be limited in its effect to the particular program, or part thereof, in which such noncompliance has been so found....

The Board argued that section 602, in effect, requires the federal government to make a finding of discrimination in the operation of each program funded by a particular grant statute. In short, if $\mathrm{HEW}$ desired to terminate Taylor County's financial assistance, it must demonstrate not simply the basic dual nature of the school system, but that a particular program was being operated in a discriminatory fashion.

In its argument before the Fifth Circuit, HEW relied heavily on the proposition that Taylor County was barred from raising the issue of programmatic findings of fact by its failure to raise that question during the administrative proceedings. ${ }^{10}$ In addition, HEW argued that a general finding of discrimination in the operation of the school system justified termination of all federal aid in the absence of a showing by the recipient that a particular program was free from discrimination. ${ }^{11}$ Finally, although almost as an afterthought, the Government argued that the Board's interpretation of section 602 was incorrect. ${ }^{12}$

The Fifth Circuit, per Judge Goldberg, rejected all of HEW's arguments and adopted the Board's interpretation of section 602 . Reading the term "program" as used in that section to mean "particular grant statute," the court held that a general departmental finding of discrimination in the operation of an elementary and secondary school system is insufficient for termination of all federal education aid to that system. In concluding that section 602 requires program-oriented findings of fact, however, the court specifically stated that such a

942 U.S.C. $\$ 2000 d-1$ (1964) (emphasis added).

10 Brief for Respondent at 10, Board of Pub. Instruction v. Finch, 414 F.2d 1062 (5th Cir. 1969).

11 Id. 15-21.

12 See id. 5a-6a. 
requirement does not mean that each program must be considered in isolation:

To say that a program in a school is free from discrimination because everyone in the school is at liberty to partake of its benefits may or may not be a tenable position. Clearly the racial composition of a school's student body, or the racial composition of its faculty may have an effect upon the particular program in question. But this may not always be the case. In deference to that possibility, the administrative agency seeking to cut off federal funds must make findings of fact indicating either that a particular program is itself administered in a discriminatory manner, or is so affected by discriminatory practices elsewhere in the school system that it thereby becomes discriminatory. ${ }^{13}$

The court did not, however, provide any guidance concerning the kind of factfinding necessary to satisfy its interpretation of section 602 . HEW was given no standards for determining what constitutes a sufficient showing of discrimination in the expenditure of federal funds under a particular grant statute or for deciding when one program is "so affected by discriminatory practices elsewhere in the school system" as to justify termination of funds.

Although the court purportedly recognized the significance of the challenge posed by the school district's interpretation of section 602 to the effective enforcement of title VI, ${ }^{14}$ its treatment of the statutory issue was neither thorough nor persuasive. It apparently concluded that the problem of statutory construction could be resolved simply by reading the termination clause and looking quickly at the legislative history. ${ }^{15}$

\section{The Termination Sanction of Title VI}

\section{A. Legislative and Administrative Development of Section 602}

Unfortunately, HEW failed to suggest and the court did not independently recognize many of the problems involved in interpreting

13414 F.2d at 1079.

14 Nominally, this case involves a challenge to the validity of an order by the Department of Health, Education and Welfare (HEW) terminating the payment of federal funds to the Board of Public Instruction of Taylor County, Florida, for violating Title VI of the Civil Rights Act of 1964. Underlying this challenge, however, is a broader question concerning the character and reach of the limitations which Congress has placed upon the power of an administrative agency to cut off federal funds and the Congressional policy behind such limitations.

Id. at 1070 (footnote omitted).

15 See id. at 1077-78. 
section 602, the "pinpoint" provision. Broadly speaking, the usual difficulties of determining legislative intent ${ }^{16}$ are aggravated in the case of the Civil Rights Act because of its highly controversial provisions and the politically charged atmosphere of its enactment. The constant maneuvering and persuasion required to secure supporting votes often precluded any single congressional understanding of the purpose of many provisions of the Act. ${ }^{17}$ In addition, formal, wellconsidered statements of the precise scope of the termination power were sparse. ${ }^{18}$ The Senate amendments to the House bill ${ }^{19}$ introduced the first explicit limitation on the termination power and were the product of an informal, bipartisan conference and were thus unaccompanied by any authoritative report. ${ }^{20}$ Furthermore, because the House elected to accept the Senate amendments without change, no conference committee report explores the impact of the pinpoint provision..$^{21}$

Nevertheless, both the language and the legislative history of title VI make clear that the pinpoint provision was enacted to limit HEW's power to terminate federal funds. Southern legislators were concerned with the possibility of arbitrary use of the broad termination power present in the House bill. ${ }^{22}$ Their concern was not assuaged by assurances that the House provision would not be interpreted as pro-

16 The illusory nature of "legislative intent" is described by Professor Witherspoon:

The chances that several hundred members of a legislature have the same determinate situations in mind as being covered or not by the language of the statute for which they vote or that a situation posited by a specific interpretive issue later presented to a court was considered by all of them and judged by all to fall within or without the coverage of the statute is so highly improbable as to be worth little argument.

Witherspoon, Administrative Discretion to Determine Statutory Meaning: "The High Road," 35 TEXAs L. REv. 63, 74 (1956).

17 It is difficult to ascertain congressional intent from circumstances surrounding the passage of the Civil Rights Act, since many of the changes made seemed directed more toward securing an adequate number of supporting votes than toward voicing a uniform purpose in any small part of the legislation.

Note, School Desegregation and the Office of Education Guidelines, 55 GEO. L.J. 325, 346-47 (1966). During the legislative debates on the Civil Rights Act, proponents were concerned over the possibility of "dealing" with Southern legislators to secure passage of the bill. See N.Y. Times, Feb. 17, 1964, at 14, col. 5. Eventually, modification of some provisions proved necessary to secure cloture and end the Senate filibuster. See id., Apr. 26, 1964, §4, at 11, col. 1.

18 Because Taylor County is the first case analyzing this precise statutory problem, no judicial statements elucidate the meaning of the pinpoint provision either. The issue was raised, but not discussed or decided in Lee County School Dist. 1 v. Gardner, 263 F. Supp. 26 (D.S.C. 1967).

19 H.R. 7152, 88th Cong., 1st Sess. (1963).

20 Bureau of National Affairs, The Civil Rights ACt of 1964, at 289 (1964). $21 \mathrm{Id}$.

22 See N.Y. Times, Feb. 8, 1964, at 1, col. 4; $i d ., 9$, col. 1 (criticism by Representatives Rain of Alabama, Whitener of North Carolina, Matthews of Florida, and Boggs of Louisiana) ; id., Mar. 25, 1964, at 20, col. 6 (criticism by Senator Johnston of South Carolina); id., Mar. 2, 1964, at 12, col. 3 (criticism by Senator Russell of Georgia). According to Representative W. M. Colmer (D. Miss.), title VI would give "every two bit bureaucrat" power "to cut the water off in your community." Id., Feb. 1, 1964, at 19, col. 3 . 
viding for a wholesale termination of federal assistance to an entire state. The fear of proponents of the Civil Rights Act that an unqualified termination provision would seriously jeopardize the entire bill, and the pressing need to secure sufficient Republican votes in the Senate to enforce cloture and end the Southern filibuster on the bill, prompted the enactment of the specific limitations of section $602 .^{23}$

Although some limitation on the termination power was certainly intended, the precise scope of the limitation was left undefined. The Fifth Circuit sought support for its restrictive reading in the congressional debate on title VI, noting several instances in which the term "program" was used synonymously with "grant statute." The cited examples, however, are inconclusive and merely demonstrate the absence of a clear and uniform interpretation of the termination power. Several of the references to individual grant statutes as "programs" were made during Senate debate on the House bill prior to the actual introduction of the pinpoint provision, and thus cannot be viewed as intentional, well-considered references to the precise language of that provision. ${ }^{24}$ Senate debate on the House bill, however, may be quite relevant to an understanding of the breadth of the termination power because, according to Senator Humphrey, ${ }^{25}$ the Senate amendments added nothing of significance, but merely expressed the existing understanding of the House bill. But the legislative history in the House provides no clear expression of the breadth of the termination power

23 See Statement by Robert H. Finch, Secy. of the Dep't of Health, Education, and Welfare and John N. Mitchell, Attorney General of the United States, July 3, 1969, on file in Biddle Law Library, University of Pennsylvania Law School.

24 The pinpoint provision, worked out primarily by Senators Humphrey and Dirksen, was part of the Senate amendments introduced on May 26, 1964. The references to "the school lunch program," cited by the court, 414 F.2d at 1077 (citing 110 CoNG. REC. 7101 (1964)), were made during the Senate debate on the House bill on April 7, 1964. One of the references to the "aid to impacted school districts [program]," id. (citing 110 CoNG. Rec. 7100 (1964)), was also made during Senate debates on the House bill.

The same problem of chronology exists with reference to the court's statement that "Senator Eastland went so far as to introduce in the Congressional Record a long list of the federal programs to which the cutoff provision was applicable . . ." Id. (citing 110 CoNG. REC. 8359-61 (1964)). Senator Eastland introduced his list on April 18, 1964, during Senate debates on H.R. 7152.

Different problems affect other illustrations offered by the court. The statements concerning the "agricultural extension program for home economics teachers" id. (citing 110 CoNG. REC. 13126 (1964)), and the "aid for vocational agriculture teaching," id. (citing 110 CoNG. REC. 13126 (1964)), were made in the context of a discussion concerning limiting the fund cutoff to the offending part of a particular state. The discussion did not focus on the second element of the pinpoint provision, that is, limitation to the particular program or part thereof.

Finally, the reference to "the farm-to-market road program," $i d$. (citing 110 Cong. Rec. 13331 (1964)), appears in a statement by Senator Gore concerning the federal funds which could be affected by a termination order. It does not appear as a definition of the term "program" as used in section 602 .

25 Senator Humphrey described the Senate changes in title VI in this way:

We have made no changes of substance in Title VI, which is concerned with discrimination in programs that receive financial assistance from the Federal Government. We have made several minor adjustments and, in addition, we have modified the language to make explicit the declared intention of this title. 110 Cong. REC. 12714 (1964). 
outlined in H.R. 7152. ${ }^{26}$ Furthermore, when the statutory issue presented requires an examination of particular language, to consider the legislators' use of key terms out of context is a questionable interpretive practice at best.

Perhaps the most blatant example of dubious use of legislative history is the court's reference to congressional discussion of the aid to impacted school districts program. ${ }^{27}$ The phrase "impacted areas school aid program" appears during debate on the House bill in a statement made by Senator Javits referring to his previous support of legislation prohibiting federal agencies from extending financial aid to segregated state programs. ${ }^{28}$ The value of Senator Javits' selfcongratulatory remarks to a close analysis of the meaning of the pinpoint provision is extremely doubtful.

Furthermore, as the Fifth Circuit itself acknowledged, the legislative debates include affirmative evidence that a broader meaning should be attributed to the term "program." The court, however, dismissed this evidence. ${ }^{29}$ Legislative history indicates that Congress was primarily concerned with two facets of the termination power: the

26 88th Cong., 1st Sess. (1963). The main House report contains no mention of any pinpoint provision for fund termination. In a submission of additional views of the Committee on the Judiciary to the Committee of the Whole House, Congressman McCulloch noted that "[i]f voluntary action fails . . . and assistance must be terminated, the termination should be pinpoint[ed] $\therefore$ to the situation where the discriminatory practices prevail' as Secretary Celebrezze has stated in his testimony. By this means, the effect of cutting off funds will be limited to the county or immediate area where racial inequality exists." This statement indicates concern with a geographical limitation of the termination power, rather than a requirement that the termination be made only with reference to particular grant statutes. H.R. REP. No. 914, 88th Cong., 1st Sess. pt. 2, at 26 (1963).

It is difficult to determine what sort of program-oriented limitation, if any, the House may have envisioned. The following discussion between Representative Meader and then Secretary of HEW Celebrezze is in terms of a broad meaning of the term "program."

Meader: You mentioned the Library Services Act. Iet's assume in an area where there is a library there is no segregation of the library so that both Negroes and whites are fully free to use the library, but in this same community Negroes are denied voting privileges. Would you, in that case... be able to withhold library funds?

Celebrezze: Not under my interpretation.

Meader: The point I was getting at is, must the discrimination under title VI relate to the particular program with respect to which the funds are withheld, or can you use the withholding [power] as a means of [ending] discrimination in other programs?

Celebrezse: It would be my interpretation [that] it would only apply to the specific program you are talking about.

Hearings on Miscellaneous Proposals Regarding the Civil Rights of Persons Within the Jurisdiction of the United States Before Subcomm. No. 5 of the Honse Comm. on the Judiciary, 88th Cong., 1st Sess. 1542-43 (1963).

27414 F.2d at 1077 (citing 110 CoNG. Rec. 7100, 13126 (1964)).

28110 CoNG. Rec. 7100 (1964).

29 See 414 F.2d at 1077. The court observed:

While it is true as HEW points out that during the Senate debate on Section 602 of the Act (42 U.S.C.A. $\$ 2000 \mathrm{~d}-1$ ) fears were expressed that termination of aid to schools might also lead to termination of aid to roads and highways . . such expressions of concern do not mark the imner limits of the Id. term "program." 
possibility that noncompliance in a single school district might lead to termination of funds to the entire state; ${ }^{30}$ and the possibility that discrimination in the education program might result in the termination of federal assistance to unrelated federally financed programs, such as highways. ${ }^{31}$

Senator Williams described consequences some congressmen feared might arise from an unlimited termination power:

Under the language of the House bill, the Federal Government would have been permitted to withhold all of the Federal funds going to a State under any program if it felt there was discrimination in any part of that program in the State. This meant that all Federal contributions toward the school lunch program, the welfare program, the program for aid to dependent children, the program for the blind, the farm program, the highway program, or any other federally supported program could have been stopped on a statewide basis solely upon the determination of the Attorney General or other agency head that a single entity, such as one school district or one local board, was in his opinion practicing discrimination. ${ }^{32}$

The political entity limitation of the pinpoint provision was enacted to resolve part of the problem described by Senator Williams. Legislators in both the House and the Senate had criticized the absence of any geographical limitation on the termination power in H.R. 7152. ${ }^{33}$ Finding scant comfort in assurances of an implied geographical limitation, Southern legislators argued that under the provisions of the House bill an entire state would be subject to loss of federal aid because of discrimination in the administration of a particular grant program in one county or city. ${ }^{34}$ Such use of the termination power would undercut any possibility of gradual desegregation; each state would be forced to guarantee immediate desegregation of all federally supported

30 Perhaps indicative of Congress' concern with eliminating cutoffs to an entire state because of discrimination in a political stubdivision is Senator Dirksen's presentation of the amended House bill.

New provisions added to this section require a finding on the record of

failure to comply with requirements under this title [title IV] and limit the

termination or refusal of assistance to the particular political entity or part

thereof or other recipient as to whom such finding is made.

110 Cong. Rec. 12818 (1964).

31 See note 29 supra.

32110 Cong. Rec. 14330 (1964).

33 See, e.g., id. 1537 (remarks of Representative Whitener).

34 See, e.g., id. 8507-08 (exchange between Senators Smathers, Allott, and Cooper including the remark by Senator Smathers that title IV was a "genocide" section because "it would punish a whole area, a whole State, a whole group, because of the sins of one"). In response to Senator Humphrey's assertion that the House bill provided for a limited termination of funds, Senator Stennis noted that "[t] he language is about as broad as one can make language. There is no limitation in it whatsoever as to area or anything else." Id. 8642 . 
facilities within its borders. Senator Humphrey offered the following explanation of the corrective effect of the pinpoint provision on this situation.

The title [VI] is designed to limit any termination of Federal assistance to the particular offenders in the particular area where the unlawful discrimination occurs. Since this was our intention, we have made this specific in the provisions of title VI by adding language to 602 to spell out these limitations more precisely. This language provides that any termination of Federal assistance will be restricted to the particular political subdivision which is violating nondiscrimination regulations established under title $V I .^{35}$

The second clause of the pinpoint provision, the program limitation, was intended to preclude the possibility of a state or county losing all forms of financial assistance because of discrimination in the operation of a particular program. ${ }^{36}$ Again, Southerners were wary of the lack of specific statutory language assuring a program-oriented termination of aid. Although the legislative debates contain many statements to the effect that the pinpoint provision of the Senate amendments assures limitation of the termination power to particular programs, ${ }^{37}$ there is no focused discussion of the meaning of the term "program." Nonetheless, the Fifth Circuit concluded that Congress intended to equate "program" with "grant statute." Under this view, the legislative purpose in enacting the program limitation was to forbid federal agencies from cutting off funds under one grant statute to coerce desegregation of facilities operated under another statute. In the context of basic education, discrimination in the operation of a title I program would not justify termination of assistance under title II of the Elementary and Secondary Education Act of 1965. Congressional discussion of the program limitation does not, however, suggest that such narrow determinations were to be required before termination. ${ }^{38}$ Nowhere does it appear that Congress intended a

35 Id. 12714-15.

36 See id. 9128 (remarks of Senator Cooper).

37 See, e.g., id. 12689 (remarks of Senator Saltonstall); id. 15896 (remarks of Representative Celler explaining the change made by the Senate amendments).

38 Insight into the meaning of the Senate amendment can be gleaned from the statements of Senators Pastore and Ribicoff. According to Senator Humphrey, particular attention was paid to their discussion of the House bill in formulating the Senate amendments to title VI. See id. 8642, 12715.

At one point in the debate, Senator Pastore noted that any action to cut off funds would have to be limited to the program in which discrimination was found. His illustrations of this point reflect a broad meaning of the term "program."

Let us assume that we are considering aid to dependent children. We would not cut off all funds for the building of a road because that is another program, although it is a Federal grant. The action must be confined to the specific program in which discrimination exists, and then only within the particular area where the discrimination takes place. There is no intent, no motive, no idea of spreading the tentacles of the Federal Government to choke off all State activity. Not at all. 
termination of funds to be limited to particular grant programs within the framework of the elementary and secondary education system when the entire system retained its dual characteristics. ${ }^{39}$

The Fifth Circuit also argued that HEW employed a narrow interpretation of the term "program" when issuing regulations under title VI. ${ }^{40}$ According to Judge Goldberg, the Department's compilation of a list of individual grant statutes and its reference to such statutes as "programs" demonstrates its awareness of the need to find discrimination in the operation of particular grant statutes and limit the termination of funds accordingly. ${ }^{41}$ Again, the court seems to be giving undue weight to the use of the term "program" out of the context of the pinpoint provision. The list of programs contained in the regulations does not indicate HEW's understanding of the proper breadth of the cutoff provision, but merely shows what funds could be affected by a termination of federal aid. In fact, the Department's consistent administrative practice has demonstrated a broad interpretation of the term "program" as it appears in section $602 .{ }^{42}$

The regulations enacted pursuant to title VI reflect HEW's view of elementary and secondary education as an indivisible entity. Section 80.4(a) requires that

[e]very application for Federal financial assistance to carry out a program ... and every application for Federal financial assistance to provide a facility shall, as a condition to its approval and the extension of any Federal financial assistance

$I d$. 7059. Unlike the various grant statutes providing assistance to the elementary and secondary education system, road grants and welfare grants involve completely unrelated activities. A second illustration offered by Pastore expressed the same concern, that school money not be used to pressure desegregation in unrelated areas:

Any nondiscrimination requirement an agency adopts must be supportable as tending to end racial discrimination with respect to the particular program or activity to which it applies . . . Thus, title VI does not authorize any cutoff or limitation of highway funds, for example, by reasons of school segregation.

Id. 7063. Senator Ribicoff agreed with this analysis of title VI:

As the Senator from Rhode Island has pointed out, if there were discrimination in one school district which refused to desegregate, we certainly would not wish to cut off public assistance or cut off road programs. Under title VI we would deal with each program separately and apply title VI only where the discrimination occurs.

Id. 7067.

39 One conclusion concerning the status of the legislative history on the "particular program" element of the pinpoint provision has been expressed in a law review note.

There was nothing to indicate that individual pieces of legislation were considered to authorize separate "programs" or that an inconsistency is created by the Office of Education's practice of considering a district's educational apparatus to be a single "program."

Note, supra note 17 , at 345 .

40414 F.2d at 1078 (citing 45 C.F.R. $\$ \$ 80.2,80.13$, Appendix A (1969)).

41 Id. at 1077-78.

42 See Note, supra note 17 , at 344 . 
- . contain or be accompanied by an assurance that the program will be conducted or the facility operated in compliance with all requirements imposed by or pursuant to this part. $^{43}$

But this requirement of individual assurances of compliance is modified with respect to federal assistance to elementary and secondary schools. Section 80.4 (c) states that the assurance requirement will be deemed satisfied if an elementary or secondary school or school system is subject to a final federal court order to desegregate and provides an assurance of compliance with that order, or if the school or school system submits a plan for desegregation which the agency approves, and provides an assurance that the plan will be carried out.44 These regulations reflect HEW's decision that the elementary and secondary education system can be most effectively dealt with, for purposes of title VI, as a single entity. Implicit in these regulations is a determination that segregated operation of an elementary or secondary education system taints every aspect of that system. ${ }^{45}$

The Department has recognized that " $[t]$ he discrimination which a child suffers during one part of the school day is not so ephemeral that it fails to affect his education during the remainder of the day." 46 If an educational system is essentially dual in nature, it is unrealistic to argue that individual programs or activities, though operated on a nondiscriminatory basis, are free from the injurious effects of segregation. HEW raised this argument before the Fifth Circuit. According to the Department, projects funded by federal money under title I of the Elementary and Secondary Education Act, ${ }^{47}$ and the outdoor center

4345 C.F.R. $\$ 80.4$ (a) (1) (1970).

44 Id. $\$ 80.4$ (c).

45 This conclusion is supported by one of the examples given in $i d$. $\S 80.5(\mathrm{~b})$.

That section provides that:

In the Federally-affected area programs . . . for construction aid and for general support of the operation of elementary or secondary schools or in programs for more limited support to stuch schools such as for the acquisition of equipment, the provision of vocational education, or the provision of guidance and counseling services, discrimination by the recipient school district in any of its elementary or secondary schools in the admission of students, or in the treatment of its students in any aspect of the educational process, is prohibited.

For the approach used for grants to institutions of higher education, see $i d$. $\S 80.4(\mathrm{~d})(2)$.

$46 \mathrm{HEW}$ Memorandum in Opposition to Petition for Further Relief at 14, Board of Pub. Instruction v. Finch, 414 F.2d 1068 (5th Cir. 1969). Under the Department's approach, "discrimination in any school program taints the entire system absolutely, preventing the school district from justifying, for example, funds for library books by showing that books purchased therewith are distributed without discrimination." Note, sipra note 17 , at 344 .

$₫ 7$ Referring to title I, HEW argued: "Even if the same federally assisted services were available at all of the elementary and secondary schools in the district, those funds are used to support instruction at elementary and secondary schools whose student bodies and faculties are segregated." HEW Memorandum in Opposition to Petition For Further Relief at 11, Board of Pub. Instruction v. Finch, 414 F.2d 1068 (5th Cir. 1969). 
funded by title III, ${ }^{48}$ were automatically infected by the existing dual school structure.

As the final element of its statutory analysis, the Fifth Circuit noted that "each of the grant statutes involved in the case before us is denominated a 'program' by the terms of its own statutory scheme." 49 According to the court,

[i]t is perfectly clear from the differing objectives and requirements of these statutes that Congress perceived educational reform as a series of problems, each requiring its own remedial measures. Congress did not attempt a comprehensive "school program," but adopted instead a series of projects each intended to reach specific areas of educational need. That this was and had been the pattern of legislative reform was clear to the proponents of Title VI in the Senate. ${ }^{50}$

Although this may be a plausible generalization of Congress' approach to educational reform, it indicates little about Congress' understanding of the breadth to be accorded particular language in the Civil Rights Act. Clearly, the scope of the termination power should be considered from the standpoint of the purpose of title VI and not from an analysis of the statutory schemes of individual grant statutes.

In short, the Fifth Circuit did not make a convincing argument in support of its restrictive reading of the termination power. Notwithstanding the court's rather facile handling of the statutory issue, the wording of the pinpoint provision and the relevant legislative history are far from conclusive. In rejecting the statutory interpretation offered by HEW, the court repudiated the consistent administrative practice of an agency.

48 Referring to the outdoor center financed under title III, HEW noted that: [I]t seems totally anachronistic for petitioner to urge in 1969 , fifteen years after Brown v. Board of Education,... that classes transported from a segregated elementary or secondary school for a brief visit to a central facility and then returned to segregated surroundings could be enjoying treatment free from the effects of discrimination.

Id. $13 \mathrm{n} .16$.

49414 F.2d at 1077-78. The court offers the following example. "20 U.S.C.A. $\$ 8441$ [sic] provides: "The Commissioner shall carry out a progrant for making grants for supplementary educational centers and services $* * *$ ? [Emphasis added]." Id. at 1078 n.14. The full statutory section reads:

The Commissioner shall carry out a program for making grants for supplementary educational centers and services, to stimulate and assist in the provision of vitally needed educational services not available in sufficient quantity or quality, and to stimulate and assist in the development and establishment of exemplary elementary and secondary school educational programs to serve as models for regular school programs.

20 U.S.C. $\$ 841$ (a) (Supp. IV, 1969). Thus, the same section uses the term "program" in both the restricted and the broad sense. Compare 20 U.S.C. \$241L (Supp. IV, 1969), cited by the court, 414 F.2d at 1078 n.14, with $\$ 241$, which refers to educational programs in the broad sense.

50414 F.2d at 1078. 


\section{B. Judicial Deference to Agency Interpretation}

Although the courts are the final interpreters of statutes, wellestablished administrative law dictates that a court must give at least some weight to the interpretation given a statute by the agency charged with its enforcement. ${ }^{51}$ This principle is well recognized in the Fifth Circuit. ${ }^{52}$ But HEW never asserted the applicability of this principle, ${ }^{53}$ and the court never considered it. HEW's arguments were based upon the assumption that its interpretation was not being challenged, or that Taylor County had not properly raised such a challenge.54 Nevertheless, in interpreting the statute, the court in Taylor County should have accorded more weight to HEW's interpretation.

Judicial deference to administrative interpretations has been dealt with by courts in two different ways: (1) agency interpretations are given some weight in the court's independent interpretation of the statute, the so-called "substituted judgment" approach, ${ }^{55}$ and (2) an

51 See Skidmore v. Swift \& Co., 323 U.S. 134, 140 (1944); Nathanson, Administrative Discretion in the Interpretation of Statutes, 3 VAND. L. REv. 470 (1950); cf. Kramer, The Place and Function of Judicial Review in the Administrative Process, 28 Fordmaxr L. Rev. 1, 84-94 (1959).

Pursuant to 42 U.S.C. $\$ 2000 \mathrm{~d}-1$ (1964), and Exec. Order No. 11247, 3 C.F.R. 348 (1964-65), the Department of Health, Education, and Welfare, and all other federal agencies and departments, were empowered and charged with the duty to enforce title VI of the Civil Rights Act of 1964.

52 See, e.g., Foremost Dairies, Inc. v. Wirtz, 381 F.2d 653, 659 (5th Cir. 1967) ; Mississippi Valley Gas Co. v. FPC, 294 F.2d 588 (5th Cir. 1961) (Congress had acquiesced in the interpretation); Louisiana Pub. Serv. Comm'n v. SEC, 235 F.2d 167,172 (5th Cir. 1956). The Fifth Circuit has recognized this principle of deference with regard to the Civil Rights Act of 1964. In Phillips v. Martin Marietta Corp., 411 F.2d 1 (5th Cir. 1969), the court noted that "it is well established administrative law that the construction put on a statute by an agency charged with administering it is entitled to deference by the courts, but the courts are the final authorities on issues of statutory construction." Id. at 3 .

53 As noted earlier, HEW did not raise the statutory issue in its written argument in Taylor Connty. Had it made a strong argument in favor of its interpretation, the court might well have considered deference. In Mazer v. Stein, 347 U.S. 201, 211-13 (1954), the Supreme Court relied on "the contemporaneous and long-continued construction of the statutes by the agency charged to administer them," in combination with the successive acts and the legislative history to show that the agency had properly interpreted Congress' intent. But if such an argument could not have been supported by experience and legislative history, then HEW was in a better position by not making any argument.

In DeSylva v. Ballentine, 351 U.S. 570 (1956), the Supreme Court rejected the argument of the Attorney General, as amicus curiae, in support of the interpretation of the Copyright Act urged by the agency, because the interpretation seemed more the result of agency resolution to fit the situation than a consistent pattern of interpretation. The Court noted that "although we would ordinarily give weight to the interpretation of an ambiguous statute by the agency charged with its administration ... we think the Copyright Office's explanation of its practice deprives the practice of any force as an interpretation of the statute . . . Id. at 577-78.

54 Brief for Respondent at 7-9, Board of Pub. Instruction v. Finch, 414 F.2d 1068 (5th Cir. 1969).

55 See, e.g., Los Angeles v. Federal Maritime Comm'n, 385 F.2d 678 (D.C. Cir. $1967)$, in which the court noted:

While an agency's construction of its statute is not binding on the courts, that construction is entitled to great weight. Petitioners must shoulder the 
agency's interpretation is conclusive if a "rational basis" for the interpretation can be found. ${ }^{56}$ The existing case law is inconsistent in this area because of each court's failure to articulate which proposition it followed. ${ }^{57}$ Professor Davis has described this problem with reference to Supreme Court decisions in the following way:

The plain fact is, for better or for worse, that we have two lines of cases, not a single line of cases, and that we have no authoritative judicial explanation of what motivates the Supreme Court in choosing between the two lines in deciding any particular case. ${ }^{58}$

According to traditional theories of administrative law, a "rational basis" standard of review is appropriate when dealing with agency findings of fact, while the more rigorous "substituted judgment" standard is to be applied when reviewing agency determinations of questions of law. But the law-fact distinction only raises the basic question in another form. It remains unclear what factors will motivate courts to denominate a particular agency finding as one of fact or of law.

The court's opinion in the present case suffers from the confused analysis described above. At no point in its opinion did the Fifth Circuit articulate the scope or direction of its judicial review. ${ }^{59}$ The court's failure to state carefully a standard of judicial review and analyze the issue of statutory construction accordingly would not present a serious problem if HEW's interpretation clearly contravened

burden of persuading us that the body charged by Congress with the day-today administration of the Shipping Act has deviated from or ignored an ascertainable legislative intention.

Id. at 681. Professor Nathanson has emphasized the importance of distinguishing these two standards for review. Nathanson, supra note 51, at 477 .

56 For a discussion of some of the factors which have influenced courts in applying a "rational basis" standard of review to questions of law, see K. C. DAVIs, ADMINISTRATIVE LAW TREATISE $\$ 30.09-.14$ (1958); Nathanson, stpra note 51, at 490-92; Schwartz, Gray vs. Powell and the Scope of Review, 54 Mich. L. Rev. 1 (1955). For illustrations of judicial application of the "rational basis" test, see United States v. Drum, 368 U.S. 370, 386 (1962) (alternatively holding a district court's substitution of its own judgment on a question of the applicability of imprecise statutory language to a particular factual situation to be an "unwarranted incursion into the administrative domain") ; NLRB v. Hearst Publications, Inc., 322 U.S. 111, 130 (1944) (applying a limited standard of review on questions of narrow application of broad statutory terms: "[I]n reviewing the Board's ultimate conclusions, it is not the court's function to substitute its own inferences of fact for the Board's, when the latter have support in the record."). A slightly different phraseology was used in Unemployment Comp. Comm'n v. Aragon, 329 U.S. 143, 153-54 (1946) ("All that is needed to support the Commission's interpretation is that it has 'warrant in the record' and a 'reasonable basis in law." ").

Professor Schwartz has argued that the "rational basis" standard is an abandonment of vital principles of judicial review. Schwartz, supra at 715 .

$57 \mathrm{~K}$. C. DAvIs, supra note 56 , at $\$ 30.08$, at 233 . Professor Davis has suggested that court decisions concerning deference to agency statutory interpretation are in large part discretionary. "A goodly portion of what happens in fact probably ought not to be articulated." Id.

58 Id. $\$ 30.07$, at 230 .

59 The lack of discussion may indicate that a "substituted judgment" standard was employed. Id. $\S 30.07$, at 229 . 
the congressional directive. ${ }^{60}$ But that was not the case here. The language of section 602 is vague, and the legislative history both sparse and inconclusive. ${ }^{61}$ In this situation, judicial deference should have been considered. The Fifth Circuit, however, never explicitly considered this issue, choosing to deal with the agency solely as a party to the proceeding. But HEW was clearly more than a litigant; in many respects, it was the "lower court" whose statutory interpretation was being reviewed. HEW deserved consideration as the initial interpreter of section 602 but was given only the consideration accorded a party.

Both deference principles are designed to aid determination of proper statutory interpretation. The reasons for giving deference to agencies in statutory interpretations are not points that HEW need have raised and argued in its case. These reasons are merely evidence of the possible correctness of the agency's interpretation. Several factors persuading courts to give weight to agency interpretations are: ${ }^{62}$ the degree of administrative expertise, which involves judicial confidence in the particular agency; the consistency of the agency's application of the particular interpretation; the length of time the interpretation has been applied; ${ }^{63}$ whether the administrative interpretation was contemporaneous with the act; ${ }^{64}$ and, whether Congress has reenacted the statute with intent to approve the agency interpretation.

The presence of these factors does not demand acceptance of the agency interpretation, but it does demand its proper consideration. The Fifth Circuit neither accepted nor considered the interpretation of HEW in light of these factors. Rather, it found the agency's interpretation wrong on its face, a determination supported by neither the language nor the legislative history of section 602 .

In Taylor County, judicial deference to an agency's interpretation was warranted by each of the criteria noted above. With regard to the criteria of agency expertise, the issue in Taylor County was arguably not the interpretation of a technical statutory provision, nor the application of broad statutory language to an individual factual situation, problems ordinarily requiring administrative determination, but the interpretation of the plain words of the statute, a task for which the

60 In such a situation, reversal of the agency's interpretation would be necessary under either standard of review.

61 See text accompanying notes 17-38 supra.

$62 \mathrm{~K}$. C. DAvis, sipra note 56 , at $\$ 30.13$, at $262-63$.

63 See Canada Packers Ltd. v. Atchison, T. \& S.F.R.R., 385 U.S. 182 (1966).

64 See Schell v. Fauché, 138 U.S. 562 (1891) ; Lindberg v. Brenner, 399 F.2d 990

(D.C. Cir. 1968).

As Justice Cardozo, in Norwegian Nitrogen Prod. v. United States, 288 U.S. 294, 315 (1933), observed:

The [administrative] practice has peculiar weight when it involves a contemporaneous construction of a statute by the men charged with the responsibility of setting its machinery in motion, of making the parts work efficiently and smoothly while they are yet untried and new. 
judiciary is most competent. ${ }^{65}$ It is unclear, however, that courts are always expert in such cases of statutory construction. The experience of the administrative agency in handling the problem at which the statute is aimed may lead to an accordance of special significance to seemingly noncontroversial statutory language. ${ }^{66}$

In view of the realities of the legislative process and the tremendously increased complexity of the federal aid to education problem in the years following enactment of title VI, to conclude that Congress was fully aware of the difficulties involved in enforcing title VI in the context of elementary and secondary education is unrealistic. Thus, because the langrage of section 602 is vague and the legislative history inconclusive, deference to HEW's interpretation was warranted. ${ }^{67}$

The other factors are also satisfied in the case of HEW interpretations of the Civil Rights Act. The Fifth Circuit has accorded great weight to the Department guidelines in judging the pace of desegregation, and has expressed confidence in HEW's ability to handle the school problem. ${ }^{68}$ Furthermore, HEW has consistently interpreted title VI from the time of its enactment as providing the authority for a termination of all federal aid to an elementary and secondary school system operated on a discriminatory basis. ${ }^{69}$ Finally, although the statute has not been reenacted, Congress has been aware of the HEW interpretation by virtue of the requirement that all termination orders be filed in advance with appropriate congressional committees. When Congress has been aware of a consistent agency interpretation, especially on so important a matter as educational funds, and has failed to

65 Professor Davis has observed that "[o]n ordinary problems of interpreting statutes, except when the subject matter is technical and nonlegal, the courts are the specialists, whether analysis of legislative history is called for, or whether the main process is one of finding the meaning of words." $K$. C. Davis, supra note 56 , at $\S 30.09$, at 242 .

66 See Peck, The Scope of Indicial Reviezs of Administrative Action in Washington, 33 WASH. L. REV. 55, 75 (1958).

67 According to Professor Nathanson,

[w] hen language is ambiguous and legislative history fragmentary and inconclusive, an administrative judgment based upon a reasoned examination of the problem in light of both the particular facts and the broad statutory objectives is likely to provide the most reliable guide to the effectuation of those objectives. If acceptance of this judgment must be reconciled with a theory of legislative intention, it might be said that the legislature presumably intended the statute to achieve its apparent objectives to the fullest extent practicable within the limits clearly defined, and that the best judges of practicability are those to whom is entrusted the primary responsibility for administration.

Nathanson, supra note 51, at 491; see Ketchikan Packing Co. v. Seaton, 267 F.2d 660 (D.C. Cir. 1959).

68 See, e.g., Singleton v. Jackson Municipal Separate School Dist., 348 F.2d 729 (5th Cir. 1965).

69 As of July 1969, HEW had terminated all education aid to 121 school districts for failure to desegregate. Statement by Robert $H$. Finch, Secy. of the Dep't of Health, Education, and Welfare and John N. Mitchell, Attorney General of the United States, July 3, 1969, on file in Biddle Law Library, University of Pennsylvania Law School. 
act to clarify or reverse that interpretation, inaction could be interpreted as approval. ${ }^{70}$

Although these factors did not require the Fifth Circuit to accept HEW's interpretation of section 602 , the court should have considered them in reaching its conclusion on the statutory issue. The Fifth Circuit treated the issue in Taylor County as an ordinary problem of statutory construction capable of resolution by analysis of language and legislative history. But neither the words of section 602 nor the congressional discussions of the termination power provide a clear answer to the meaning of the pinpoint provision. Thus, the court should have considered the broader issues raised in Taylor County: the congressional purpose in enacting title VI, ${ }^{71}$ the effectiveness of the termination sanction in achieving desegregated education, and the potential burden created by a restrictive reading of the pinpoint provision.

\section{Alternative Technigues for Entorcing Desegregated EdUCATION}

Title VI of the 1964 Civil Rights Act reflects congressional awareness of the inability of federal courts to handle the complex problems of school desegregation. ${ }^{72}$ The scant progress made in the courtroom during the decade following Brown v. Board of Education ${ }^{\mathbf{7 3}}$ necessi-

70 Some judicial opinions have attached significance to congressional inaction following consistent administrative interpretation of a statute. For example, in Costanzo v. Tillinghast, 287 U.S. 341 (1932), involving interpretation of a statutory provision governing deportation of aliens, the Court noted that "[ $t]$ he failure of Congress to alter or amend the section, notwithstanding this consistent construction by the department charged with its enforcement, creates a presumption in favor of the administrative interpretation to which we should give great weight, even if we doubted the correctness of the ruling of the Department of Labor." Id. at 345.

But the pitfalls of attaching significance to legislative inaction have also been recognized. See Power Reactor Dev. Co. v. International Union of Elec., Radio, \& Mach. Workers, 367 U.S. 396, 409 (1961) ; TIME Inc. v. United States, 359 U..S. 464, 477-78 (1959) ; Porter v. Mohawk Wrecking \& Lumber Co., 156 F.2d 891, 895 (5th Cir. 1946). See generally 43 CALIF. L. REv. 907 (1955).

In any event, the statutory requirements of referring termination orders to committees of Congress, and presidential approval of implementing regulations, probably brought attention to the HEW approach. See N.Y. Times, Dec. 5, 1964, at 1, col. 6 .

71 In Miller v. Amusement Enterprises, Inc., 394 F.2d 342 (5th Cir. 1968), the Fifth Circuit recognized the need to look beyond the language of the Civil Rights Act in cases of statutory construction. The court observed:

We are not only dealing with the language of the statute, but we must look as well to the logic of Congress and the broad national policy which was evidenced by its enactment. Our system does not favor mechanical jurisprudence; it seeks to find the purpose and spirit of a statute and the intention of its makers.

Id. at 353 .

72 Dunn, Title VI, The Guidelines and School Desegregation in the South, 53 VA. L. Rev. 42, $42-43$ (1967); see Note, ". . . With All Deliberate Speed", 1968 U. ILL.

L. FORUM 105, 144:

The provisions of Titles 4 and 6 worked a major change in the patterns of school desegregation. Whereas school boards had, in the past, been able to segregate with relative impunity, depending on the law of averages to protect them from the relatively infrequent private desegregation suits, they now faced a two-pronged governmental attack.

73347 U.S. 483 (1954). 
tated the use of more effective means-the federal purse-for realizing the principle of equal educational opportunity. ${ }^{\mathbf{7 4}}$ Title VI effected a basic reallocation of federal policy enforcement in the area of education by requiring HEW to assume a large share of the responsibility for monitoring Southern school desegregation, and by replacing the court order with the termination of federal funds as the sanction for assuring compliance. $^{75}$

Despite criticism of federal reluctance to employ the termination power to the fullest extent possible, ${ }^{76}$ progress in school desegregation has been primarily the result of administrative, and not judicial, enforcement. ${ }^{77}$ In 1964 , only 2.25 percent of all Negro school children in the eleven states of the Confederacy attended schools with white children. $^{78}$ By the 1965-66 school year, this figure had been tripled, largely through the efforts of HEW. ${ }^{79}$ More recent figures lend further support to the value of the title VI program. ${ }^{30}$ Experience since 1964 has clearly shown that the actual termination of federal funds may succeed where threats of termination, efforts to secure voluntary compliance, and litigation prove ineffective. ${ }^{81}$

The importance of the title VI administrative proceeding has been underscored by the commitment of large sums of federal money to state education under the Elementary and Secondary Education Act of 1965. ${ }^{82}$ According to one observer:

74 According to the report of the White House Conference on Civil Rights, the use of the termination power presents the only hope for effectuation of school desegregation.

It was the Congressional purpose, in Title VI of the Civil Rights Act of 1964, to remove school desegregation efforts from the courts, where they had been bogged down for more than a decade. Unless the power of the Federal purse is more effectively utilized, resistance to national policy will continue and, in fact, will be reinforced.

Conncil's Report and Recommentations to the Conference, in WHITE House CoNFERENCE "To Fulfill These RIghts" 41 (1966) [hereinafter cited as Council's Report].

75 See Note, The Courts, HEW, and Southern School Desegregation, 77 YALE L.J. 321, 322 (1967).

${ }^{76}$ See Conncil's Report; Lieberman, The Civil Rights Fiasco in Public Edncation, 47 Phi Delta Kappan 482, 485 (1966).

77 Carter, Equal Educational Opportunities for Negroes-Abstraction or Reality, 1968 ILL. L. FORUM 160, 176; Dunn, supra note 72, at 43-44. To a great extent, title VI operates invisibly. According to HEW, "the success of Title VI is not measured by the relatively small number of terminations, but rather by the large number of recipient districts which, because of Title VI, have been induced to cease discrimination without court action." HEW Memorandum in Opposition to Petition for Further Relief at 24, Board of Pub. Instruction v. Finch, 414 F.2d 1068 (5th Cir. 1969).

78 United States Comm'n on Civil Rights, Survex of School Desegregation IN THE SOUTHERN AND BORdER STATES, 1965-66, at 1 (1966) [hereinafter cited as SURVEY] ; see Carter, supra note 77, at 160, 176.

79 Carter, supra note 77, at 174-76.

so See HEW News (Jan. 4, 1970).

81 G. Orfield, The Reconstruction of Southern Education: The Schools AND THE 1964 CIVIL RIgHTS ACT 142 (1969).

8220 U.S.C. $\$ \S 241 \mathrm{a}-241 \mathrm{~m}$ (Supp. IV, 1969). 
The Elementary and Secondary Education Act of 1965 greatly increased the amount of federal money available for public schools, and did so in accordance with a formula that pumps the lion's share of the money to low-income areas such as the Deep South. Consequently, Title VI of the Civil Rights Act of 1964 has become the main instrument for accelerating and completing the desegregation of Southern public schools. ${ }^{83}$

In view of the central role played by title VI proceedings in the attempt to realize equality of educational opportunity, the potential limitation on the termination power announced in Taylor County is a matter of serious concern.

The significance of any limitation on the termination power should be viewed in the context of the problems confronted when other methods of enforcing the Civil Rights Act are used. ${ }^{84}$ In Davis v. Board of School Commissioners, ${ }^{85}$ the Fifth Circuit noted some of the substantive problems involved in judicial determination and enforcement of desegregation standards. Because the time lag between the issuance of the order of the district court and argument before the appellate court may be substantial, it is quite possible that desegregation standards may have evolved beyond those on which the order was based. ${ }^{86}$ Evolving standards require the appellate courts continually to reevaluate the applicable law. ${ }^{87}$ This problem of identifying desegregation standards is augmented by the difficulty of securing compliance from possibly recalcitrant district courts. ${ }^{88}$

Despite such problems, it has been suggested that "courts are still as well-equipped procedurally as the Office of Education to enforce the desegregation of a particular school district once that school district has come before the court." 89 Serious problems exist, however, in bringing school districts before the court and securing full adjudication within a reasonable time. Delay and deliberate obstructionism by school districts has severely weakened private litigation as an instrument of enforcement ${ }^{90}$ In addition, Negro litigants often face intimidation ranging from loss of jobs and other economic reprisals to actual physical violence. ${ }^{91}$ These difficulties are aggravated by a severe short-

83 Bickel, Forcing Desegregation Throngh Title VI, New Republic, Apr. 9, 1966 , at 8.

84 See Note, supra note 17, at 348. See generally Bernhard \& Natalie, Between Rights and Remedies, 53 GEo. L.J. 915 (1965).

85364 F.2d 896 (5th Cir. 1966).

$88 \mathrm{Id}$. at 898.

87 Id.

$88 I d$.

so Note, supra note 75 , at 353.

90 See Gellhorn, A Decade of Desegregation-Retrospect and Prospect, 9 UTaH L. REv. 3, 5-6 (1964).

01 See Knowles, School Desegregation, 42 N.C.L. REv. 67, 76-78 (1963); cf. Amsterdam, Unsettling Settled Questions in the Law of Civil Rights, 39 F.R.D. 484, 
age of available legal talent in the civil rights area, ${ }^{22}$ a problem perhaps attributable to the time-consuming nature of most constitutional litigation, and the pressure of community hostility. Finally, public identification and harassment of members of such organizations as the NAACP have impeded their efforts to provide competent counsel to Negro plaintiffs lacking litigation funds. ${ }^{93}$

The Civil Rights Act provides for suits by the Attorney General to enforce timely compliance with desegregation requirements. ${ }^{94}$ This procedure may avoid some of the problems associated with private litigation. For example, the lack of funds to pursue desegregation suits, even though Negro litigants are available and willing, would no longer be an insurmountable barrier. ${ }^{95}$ The above-mentioned economic and extra-legal sanctions would probably seldom be applied to parties represented by the Department of Justice. ${ }^{96}$ Finally, the problems stemming from the paucity of legal talent in the civil rights field would be alleviated to some extent. ${ }^{97}$ Nevertheless, suits initiated by the Attorney General will not solve all the problems in this area. In view of the generally protracted nature of desegregation litigation, the thousands of school districts requiring attention, and the staff and time limitations operating on the Government, it is difficult to conclude that the Attorney General will be able to shoulder the major burden. ${ }^{98}$ In addition, the degree of initiative exercised by the Attorney General in school desegregation suits may depend upon political pressures and the varying attitudes of each administration toward the school problem.

486 (1966) ; Note, Parties Plaintiff in Civil Rights Litigation, 68 ColUM. L. Rev. $893,898-99$ (1968). litigant:

One author offers the following description of the plight of the constitutional

The constitutional litigant is beset by the customary client's problems-how the case will affect his family and his job, how he will be described in the newspapers, what will happen when the case is over. But all of these concerns are heightened for the constitutional client because he is-sometimes unwittingly-at the center of a movement for social change and he often comes to personify that movement.

Ginger, Legal Processes: Litigation As A Form of Political Action, in LEgaL. Aspects of the Civil Rights Movement 204 (D. King \& C. Quick eds. 1965). 92 Ginger, sipra note 91, at 202. Professor Kaplan has noted that "except for the overworked attorneys of the Legal Defense Fund, the quality of legal representation for Negro plaintiffs has, in the main, been poor indeed." Kaplan, Comment, 64 Colum. L. Rev. 222, 227 (1964).

${ }^{93}$ See McKay, "With All Deliberate Speed:" Legislative Reaction and Judicial Development 1956-57, 43 VA. L. REv. 1205, 1235 (1957).

9442 U.S.C. $\$ 2000 \mathrm{a}-5$ (1964).

95 See Kaplan, supra note 92 , at 226-27.

$96 I d$.

87 Id. $227-28$.

98 According to Professor Bickel, "Given the judicial resources that are available, and given, indeed, the resources that can conceivably be made available to the Attorney General himself, it is still out of the question that desegregation can be achieved wholly or even chiefly through litigation." Bickel, The Decade of School Desegregation Progress and Prospects, 64 CoLvM. L. REv. 193, 219 (1964). 
Neither HEW nor the Fifth Circuit mentioned the burden placed on HEW by title VI of the Civil Rights Act or attempted to determine the extent to which that burden would be increased by a requirement of programmatic findings of fact. Such considerations are relevant to a determination of the meaning of the pinpoint provision of section 602 , because it cannot be presumed that Congress would establish the termination power on one hand and block its effective implementation on the other.99

The Civil Rights Commission has described the tremendous responsibility assumed by the Department of Health, Education, and Welfare:

In April, 1965, the Office of Education was faced with the massive task of determining whether 4,941 school districts in the Southern and border states, each unique, were in compliance with the standards adopted by that office to implement Title VI. ${ }^{100}$

It was originally hoped that state education agencies would assume a position of responsibility in the effort to achieve desegregation of local school districts. ${ }^{101}$ Initial hopes, however, were frustrated by the inability or unwillingness of local districts to act voluntarily. The Office of Education was forced to establish standards for desegregation and to insure their enforcement. ${ }^{102}$ The result was an enormous increase in the volume of Department work required for proper evaluation of assurances of compliance and of particular desegregation plans submitted by local districts. Time and additional manpower had to be expended pursuading school officials to adhere to previously submitted plans and in initiating administrative proceedings against intractable districts. ${ }^{103}$

Despite the progress made in the last six years, a significant core of resistance to $\mathrm{HEW}$ desegregation requirements remains. ${ }^{104}$ Moreover, HEW must determine whether school districts ostensibly desegregating under accepted plans are, in fact, meeting the obligations of these plans. In short, HEW's task is far from complete. Whether or not it will be accomplished depends in part upon the effect of the Taylor County decision..

The huge sums of money administered and the large number of state and local educational agencies involved in the process underscore

99 See Note, supra note 17 , at $325,346$.

100 SuRvey 25; see Bailey \& Mosher, Implementation of Title VI of the Civil Rights Act, 49 PHI DeLta Kappan 300 (1967-68).

101 Note, supra note 75, at 321, 345.

102 Id.

103 SuRvey 25-26.

104 See Statement by Robert Finch, Secy. of the Dep't of Health, Education, and Welfare and John N. Mitchell, Attorney General of the United States, at 4, July 3,1969 , on file in Biddle Law Library, University of Pennsylvania Law School. 
the difficulty of HEW's task. For example, under title I of the Elementary and Secondary Education Act, which funds programs for educationally deprived children, 9.2 million school children in 16,000 school districts participated in fiscal $1968 ;{ }^{105} 1.12$ billion dollars were allocated for fiscal 1969.108 The federal formula for determining eligibility includes ninety percent of the school districts in the fifty states, the District of Columbia, American Samoa, Guam, Puerto Rico, the Virgin Islands, and the trust territory of the Pacific Islands. ${ }^{107}$

Inadequate and overly centralized staffing has also impeded HEW's efforts to enforce title VI effectively. ${ }^{108}$ The drain on manpower resulting from the demands of administrative detail inhibits $\mathrm{HEW}$ from conducting the field investigations crucial to determinations of actual compliance. ${ }^{109}$ Administrative necessity required the adoption of minimum desegregation percentages as a test of good faith effort. ${ }^{110}$ A recent attempt to reorganize on a regional basis has not been completely successful; administrative difficulties persist. ${ }^{111}$

HEW's task is made more difficult by the complex, time-consuming process prerequisite to a termination of federal funds. ${ }^{112}$ The process is so extended that it has been suggested that the effective use of the

105 U.S. Burgau of Elementary and Secondary Education, Office of EducaTion, PRograMs 9 (1969).

$108 I d$.

107 Id. Under title III, Supplementary Educational Centers and Services, 1800 active projects, at a total cost of $\$ 187$ million, are reaching approximately 10 million elementary and secondary school children, 135,000 preschoolers, 67,000 out-of-school youths, 300,000 teachers, and 131,000 parents and other adults. Currently, 7200 school districts are participating under title III. For fiscal 1969, \$165 million were allocated. Id. 14.

108 See Lieberman, supra note 76 , at 485 ; Note, supra note 75 , at 321,354 . The White House Conference on Civil Rights concluded:

To achieve the intended results, the Office of Education must provide for a much enlarged technical staff, insist that compliance calls for meeting both the letter and the spirit of the law, and develop more prompt and efficient machinery for withholding or terminating Federal aid where reasonable compliance efforts have failed.

Council Report 41.

109 SURVEY 25-26. The inadequate number of trained professionals necessitated the hiring of summer law students to check complaints and conduct investigations. Hearings on Policies and Guidelines for School Desegregation Before the House Rules Comm., 89th Cong., 2d. Sess., pt. 1, at 52 (1966) (remarks of Harold Howe II, U.S. Comm'r of Education, Dep't of Health, Education, and Welfare).

110 [I]n administrative terms, there was simply no conceivable way in which a tiny staff in Washington could accurately assess the subtleties of local resistance used to subvert free-choice plans. Only by creating an administrative presumption of noncompliance if performance fell below a specified minimum did the problem become manageable.

G. ORFIELD, sipra note 81 , at 142 .

111 Note, supra note 75 , at $321,347$.

112 The procedure has been described less charitably as "cumbersome." Id. 353; see Rachlin, The 1964 Civil Rights Law: $A$ Hard Look, 2 LAw IN TRANs. Q. 67,79 (1965). Edwin Yourman, Assistant General Counsel for HEW, estimated that average termination proceedings last over one year. Interview in Washington, D. C., Oct. 15, 1969. 
termination power depends in part on a failure by school districts to take full advantage of existing procedural rights. ${ }^{113}$ Of course, in dealing with so sensitive an issue as the termination of federal funds, procedural safeguards are necessary as a check against hasty or indiscriminate application of the sanction. ${ }^{114}$ But the resulting burden on HEW should be recognized.

Briefly, the HEW regulations require written notice of title VI proceedings ${ }^{115}$ and an answer within twenty days by the respondent school district. ${ }^{116}$ HEW may amend its notice of hearing once as a matter of course before service of the school district's answer, ${ }^{117}$ and the school district may amend its answer subject to certain time limitations. ${ }^{118}$ Following the hearing, the presiding officer, depending upon his authority, either renders an initial decision or certifies his findings and a recommended decision to the proper department official. ${ }^{119} \mathrm{Ex}$ ceptions and responses may then be filed with the reviewing authority and a decision on the exceptions made. ${ }^{120}$ A petition for discretionary review by the Secretary of HEW may be filed, ${ }^{121}$ followed by judicial review according to the Administrative Procedure Act. ${ }^{122}$ Furthermore, termination proceedings cannot be initiated until it has been demonstrated that voluntary compliance efforts have been unsuccessful. ${ }^{123}$ Actual termination cannot take place until a copy of the termination order has been filed with the appropriate committee of Congress. ${ }^{124}$

In view of the mechanics of federal fund allocation and staff limitations which characterize HEW, a requirement of program-oriented findings of fact will create additional obstacles to the effective enforcement of title VI. ${ }^{125}$

113 Many school districts have not contested the proceedings, but a concerted effort to thwart the administrative process by all school districts taking full advantage of all their procedural rights would at least delay the effectiveness of the enforcement proceedings, given the smallness of the Office of Education litigation staff.

Note, supra note 75 , at 353.

114 See 110 Cong. REC. 8642 (1964) (remarks of Senator Pastore); id. 12617 (1964) (remarks of Senator Muskie).

11545 C.F.R. $\$ 81.51$ (1970).

$116 I d . \$ 81.52$.

117 Id. § 81.53.

$118 I d$.

119 Id. $\$ 81.102$.

120 Id. $\$ 81.103$.

121 Id. $\$ 81.106$.

12242 U.S.C. $\$ 2000 \mathrm{~d}-2$ (1964).

123 Id. $\$ 2000$ d-1 (1964).

124 Id. Although Congress is given no apparent power at this stage, calling the agency before the committee may well discourage termination proceedings in some cases. Rachlin, supra note 112, at 80 .

125 It has been suggested that requiring HEW to tie each dollar cut off to a discriminatory practice would "render the section [Title VI] essentially ineffective as applied to school desegregation." Note, supra note 39, at 346 .

According to $\mathrm{HEW}$, such a requirement, in light of funding arrangements and 
The federal government allocates financial assistance according to two basic funding arrangements. ${ }^{126}$ Under one, federal funds are administered directly to local school districts. The bulk of federal money, however, is distributed to the state education agency which assumes full responsibility for redistribution to local school districts. In most cases, HEW does not maintain records of the exact amount of federal money subgranted to particular districts or of the nature of individual projects supported by federal funds. ${ }^{127}$

Because the Taylor County decision requires HEW to make findings of discrimination in the operation of individual grant statutes, an additional burden is placed on $\mathrm{HEW}$ to secure information regarding the precise use of federal funds. States agencies themselves may be unable to describe the current use of the federal funds dispensed by them, although the various grant statutes generally require the local recipient to submit to the state agency an annual report on the use of federal funds, and such other reports as the state agency may require, ${ }^{128}$ just as similar provisions require reports from state to federal agencies. ${ }^{129}$ In response to the apparent mandate of Taylor County, HEW has prepared and distributed a form ${ }^{\mathbf{1 3 0}}$ to individual school districts designed to trace the sources, amounts, and usages of all federal funds in the district. This newly imposed requirement to receive and process grant statute reports not only from the states but also from the individual districts obviously increases the paper work burden on HEW staff members, assuming local officials are willing to comply.

Unfortunately, these statutory provisions and the HEW form do not necessarily provide an easy answer to the problem presented by Taylor County. The federal government must rely on the good faith cooperation of state and local education agencies. In view of the statutory provisions for reporting, an agency will be unlikely simply to refuse to provide the necessary information. There is ample opportunity,

the extent of available information, would place an intolerable burden on the Department.

If . the General Counsel must prove what money is in what pipeline, and at what point in the pipeline, before he can obtain an order terminating, refusing to grant and to continue Federal financial assistance for use by any particular school district under its program, and if the order is restricted to intercepting that particular money, then effective enforcement of Title VI is impossible.

HEW Brief at 40, Barbour Co., Ala., C.R. No. 2 (1965); see Note, Federal Aid to Higher Education: The Challenge to Fraternal Freedom of Association, 1966 WISC. L. REv. 1252, 1256.

126 HEW Brief at 30-31, Barbour Co., Ala., C.R. No. 2 (1965).

$127 \mathrm{HEW}$ Memorandum in Opposition to Petition for Further Relief at 8 n.10. Board of Pub. Instruction v. Finch, 414 F.2d 1068 (5th Cir. 1969).

128 See, e.g., 20 U.S.C. $\$ 241$ (a) (7) (Supp. IV, 1969).

129 See, e.g., id. $\$ 241 \mathrm{f}(\mathrm{c})(3)$.

$130 \mathrm{HEW}$, Report to the Department of Health, Education and Welfare, pursuant to 45 C.F.R. $\S 80.66$ on the specific uses of federal financial assistance. 
however, for school districts or states to submit confusing or inconclusive information, particularly with reference to grant statute programs supporting numerous distinct projects. ${ }^{131}$ As one federal official has observed, reports from state and local agencies generally refer to project numbers, or some other general description of fund usage, and seldom contain an exact statement of what is being done. ${ }^{132}$ A determination of either program mechanisms or project beneficiaries requires timeconsuming reference to individually filed applications at federal and state levels. ${ }^{133}$

Most importantly, even after this information is gathered, it may not be meaningful to an HEW staff member unfamiliar with local or state customs and conditions. ${ }^{134}$ Thus additional field investigations may be necessary. When several projects are simultaneously supported by a single grant statute, the burden of unraveling a single program and monitoring its implementation within the district becomes extremely complex. ${ }^{135}$

Even if adequate information concerning current use of federal assistance for elementary and secondary education is available, problems arise if the school district shifts funds into a new or different program. HEW described the difficulty in this way:

Each time a use was found to be affected by the discrimination, the school district could simply announce a different use within its elementary and secondary school system and thus require new findings which would have to be preceded by a lengthy administrative process. Title VI would have little influence on and would provide little impetus for correction of the basic discrimination. ${ }^{136}$

Although this result is obviously intolerable from an administrative standpoint, it would seem to follow from the Taylor County holding

131 In addition to the basic problem of recalcitrant educational agencies, requesting additional reporting and information presents other difficulties. According to Bailey \& Mosher, "reporting usually connotes an authority-subordinate relationship. The drafters of ESEA [Elementary and Secondary Education Act] had scrupulously attempted to avoid language which would suggest that reporting requirements were tantamount to Federal control of State and local educational administration." Bailey $\&$ Mosher, supra, Note 100, at 124 . Thus, the Taylor County requirement and the resultant need for a closer federal check on the disbursement of government money may aggravate already strained relations in the sensitive area of federal aid to education.

132 Letter from Lloyd R. Henderson, Education Branch Chief, Office for Civil Rights, to the University of Pennsylvania Law Review, Dec. 22, 1969.

133 Id.

$134 I d$.

135 Interview with Thomas C. Rosica, Director of Federal Programs for the School District of Philadelphia, in Philadelphia, Dec. 17, 1969.

$136 \mathrm{HEW}$ Memorandum in Opposition to Petition for Further Relief at 25, Board of Pub. Instruction v. Finch, 414 F.2d 1068 (5th Cir. 1969). 
that a termination order applies only to the specific use described in a formal finding of discrimination.

The Taylor County requirement may also impede the exercise of other powers specifically granted to federal agencies under the Civil Rights Act. Section 602 states in part that compliance with rules adopted pursuant to that section may be achieved by the "termination of or refusal to grant or to continue assistance . . . ."137 Because determinations in advance of whether a school district will use particular federal funds in a discriminatory manner would be extremely diffcult, a requirement of program-oriented findings of fact would make an initial refusal to grant federal funds virtually impossible..$^{138}$

These considerations support HEW's interpretation of the pinpoint provision of section 602. But as the Fifth Circuit noted, even if HEW's argument that the term "program" refers to the broad elementary and secondary education program is accepted, some meaning must be given to the words "or part thereof." ${ }^{139}$ According to the court, these words refer to the individual grant statute. ${ }^{140}$ But another interpretation is possible.

As noted earlier, during the congressional debates much concern was expressed over the possibility of a statewide termination of aid. ${ }^{\mathbf{1 4 1}}$ The political entity limitation was intended to obviate the problem of an entire state losing federal education assistance because of the discrimination prevailing in a particular school district. But it must be remembered that title VI applies to all federally assisted activities, not just to those, such as education, which are normally controlled at the local level. It was the fear of some legislators, notably Senator Gore, that in the case of programs administered on a state basis-that is, directly by a state agency - the political entity limitation would be ineffective in attempting to pinpoint the termination of federal aid. Senator Gore expressed the following reservations about the effectiveness of the Dirksen amendments :

Concern had been expressed by some, including myself, that the language of the bill would authorize termination of aid to an entire State, even though the discrimination might be alleged to exist in only one county of that State. The language of the substitute (the Dirksen amendment), even though intended to prevent this result, does not, in my opinion, do so in many programs. There are many types of Federal aid programs. The procedures by which these programs are administered vary substantially. Under those

13742 U.S.C. \$2000d-1 (1964).

138 HEW Brief at 44, Barbour Co., Ala., C.R. No. 2 (1965).

139414 F.2d at 1077.

$140 \mathrm{Id}$.

141 See text accompanying notes $33-34$ supra. 
programs which are administered by the States, statutory requirements may preclude the termination or the withholding of aid on any basis other than a statewide basis. In such cases those who would administer the provisions of Title VI, under either the language of the substitute or the language of the original bill, might well find that they must terminate aid to the entire State or not terminate it at all. In many aid programs, the State is the "recipient" of the "assistance." In such cases, there is no direct relationship, contractual or otherwise, between the Federal Government and a local political subdivision. ${ }^{142}$

If this analysis is correct, it cannot be argued that the "or part thereof" language of the political entity limitation would obviate the necessity of a statewide cutoff in cases of state administered programs. Section 602 limits the termination or refusal of assistance to "the particular political entity, or part thereof, or other recipient as to whom such a finding has been made . . . ."143 According to Senator Gore, in state administered federal aid programs the state would be the "recipient" of federal funds as that term is used in section 602 and as such would be subject to the termination provisions of title VI.

This program may be overcome if the "part thereof" language of the program limitation is viewed as a corollary to the political entity limitation. That is, in cases of state administered programs, involving no political subdivisions, the "part thereof" language may avoid the necessity of a statewide cutoff when discrimination exists only in particular locations. This interpretation of the "part thereof" language, suggested during the debates by Senator Ribicoff ${ }^{144}$ and adopted by HEW, ${ }^{145}$ is completely consistent with the policy of the Act and imposes far less of an administrative burden on the Department.

142110 CONG. REC. 13126 (1964).

14342 U.S.C. $\$ 2000 d-1$ (1964) (emphasis added).

144 In response to the fears expressed by Senator Gore, Senator Ribicoff stated: It should be pointed out that the new language mentioned by the Senator from Tennessee provides that any fund cutoff must be limited not only to the particular program in which discrimination occurs, but also must be limited to the part of the program in which discrimination occurs.

It is my understanding, with the language placed in the Dirksen-Mansfield substitute, that what now takes place . . . is that in a State having 100 counties and receiving $\$ 100,000$, each county receiving $\$ 1,000$, should one county discriminate under the language previously used, it could have been argued that the State would lose $\$ 100,000$. Under the language of the Dirksen-Mansfield substitute, it is my understanding that what would actually take place ... would be that the State would receive $\$ 99,000$, and that they would distribute the $\$ 99,000, \$ 1,000$ to each of the 99 counties, but would not make any distribution to the one county that was in the process of discriminating.

110 CoNG. Rec. 13126 (1964).

145 Brief for Respondent at 6a, Board of Pub. Instruction v. Finch, 414 F.2d 1068 (5th Cir. 1969). 


\section{CONCLUSION}

Since the passage of the 1964 Civil Rights Act, progress in desegregating Southern schools has been an administrative rather than a judicial accomplishment. Armed with the effective sanction of terminating aid to recalcitrant school districts, the Department of Health, Education and Welfare had become both the spearhead and overseer of the integration effort. By impairing the effectiveness of this statutory goad, Taylor County has seriously stifled the power and expedition once given HEW to force the pace of Southern school desegregation. Termination may in fact injure those whom the Act was initially intended to benefit, and the probability of this result must be weighed against the larger goal of integrated schools. But in view of HEW's prior success in hastening desegregation, the balance is clearly in favor of a less restricted power to sever federal funds.

Mark O. Heaney 